\title{
MODEL AGILE SUPPLY CHAIN INDUSTRI PERIKANAN DI KOTA AMBON
}

\author{
Alfredo Tutuhatunewa \\ e-mail: alfredo.tutuhatunewa@fatek.unpatti.ac.id \\ Fakultas Teknik Universitas Pattimura, Kampus Poka - Ambon 97233, Maluku, Indonesia
}

\begin{abstract}
ABSTRAK
Provinsi Maluku sebagai provinsi yang memiliki luas lautan yang begitu besar, dengan sendirinya memiliki kekayaan sumber daya laut yang beraneka ragam dan potensial untuk dikelola. Kekayaan sumber daya laut tersebut berupa sumber daya ikan maupun non ikan.

Penelitian ini merupakan kombinasi dari penelitian deskriptif, penelitian pengembangan dan penelitian verifikasi. Survei lapangan dilakukan untuk mendapat gambaran awal mengenai permasalahan yang dikaji, yaitu kondisi SC industri perikanan di Kota Ambon. Studi literatur digunakan untuk mengumpulkan dan mendapat gambaran utuh mengenai permasalahan SC industri perikanan dan Agile Supply Chain (ASC). Berdasarkan survei lapangan dan studi literatur, dikembangkan dan diformulasikan kerangka konsep ASC Industri Perikanan di Kota Ambon. Pada penelitian ini, obyek penelitian adalah seluruh pelaku SC industri perikanan di Kota Ambon. Metode pengambilan sampel yang digunakan adalah Non Probability Sampling.
\end{abstract}

Kata kunci: Agile supply chain, Industri perikanan, Sistem Logistik.

\section{PENDAHULUAN}

Provinsi Maluku sebagai provinsi yang memiliki luas lautan yang begitu besar, dengan sendirinya memiliki kekayaan sumber daya laut yang beraneka ragam dan potensial untuk dikelola. Kekayaan sumber daya laut tersebut berupa sumber daya ikan maupun non ikan. Potensi ini dapat dikembangkan sebagai penghasil devisa bagi daerah maupun negara. Potensi perikanan yang potensial untuk dikembangkan antara lain jenis ikan pelagis besar (tuna, cakalang, tongkol, tenggiri), jenis-jenis marlin, cucut, serta ikan dasar dan ikan karang. Dengan potensi yang ada, Kementerian Perdagangan terus mendorong ekspor perikanan Maluku untuk menjadi salah satu sektor andalan ekpor Indonesia ke Eropa dan Amerika.

Sejalan dengan potensi kekayaan sumber daya laut, investasi untuk sektor perikanan juga terus ditingkatkan. Investasi pada sektor perikanan dapat dilakukan dalam bentuk perikanan budidaya atau perikanan tangkap. Untuk perikanan tangkap, pada bagian hulu dapat dikembangkan usaha pengadaan kapal, pasokan es dan Cold Storage. Sedangkan pada bagian hilir dapat dikembangkan usaha pengolahan komoditas kaleng, komoditas beku, dan komoditas segar. Disamping adanya kegiatan pengasapan ikan yang dapat dipasarkan untuk memasok kebutuhan lokal, regional (intra wilayah Maluku) dan nasional, selain itu juga dikembangkan usaha rumah makan/restoran. Untuk perikanan budidaya, usaha yang potensial dikembangkan adalah kolam pancing dan ekowisata.

Dalam sistem logistik, ikan merupakan produk yang membutuhkan penanganan berbeda dibandingkan dengan komoditi lainnya. Ikan adalah produk yang sangat tidak tahan lama, sehingga perlu penanganan logistik yang lebih kompleks serta biaya yang mahal, terutama untuk penyimpanannya. Ikan juga memiliki sifat umur penggunaan yang pendek serta tingkat kerentanan yang tinggi terhadap cuaca, sehingga diperlukan penanganan khusus dalam proses pengepakan dan distribusinya.

Hal ini menunjukkan kompleksitas proses pasokan dan distribusi produk perikanan, yang melibatkan banyak pihak, diantaranya adalah nelayan, pedagang kecil, pedagang besar, pabrik, eksportir, pemerintah hingga masyarakat sebagai konsumen akhir. Untuk itu, perlu dibangun suatu model Supply Chain (SC) perikanan yang komprehensif untuk mewujudkan terselenggaranya aktivitas di sektor kelautan dan perikanan yang andal, dan mempunyai daya saing global.

Strategi pendekatan SCM digunakan untuk meningkatkan daya saing pemasaran, baik di pasar dalam negeri maupun pasar internasional, yang dilakukan sebagai upaya untuk menyediakan produk melimpah dengan mutu tinggi dan diproduksi dengan biaya efisien. Pendekatan SCM dilakukan agar peningkatan daya saing itu tidak semata dilakukan melalui perbaikan produktivitas dan kualitas produk, tetapi juga melalui pengemasan, pemberian merk, efisiensi, transportasi, informasi, penguatan kelembagaan dan penciptaan inovasi secara kontinyu dan sistematik (Dirjen Hortikultura, 2008).

Kompleksitas proses pasokan dan distribusi produk perikanan melibatkan banyak pihak, diantaranya adalah nelayan, pedagang kecil, 
pedagang besar, pabrik, eksportir, pemerintah hingga masyarakat sebagai konsumen akhir. Untuk itu, perlu dibangun suatu model Supply Chain (SC) perikanan yang komprehensif dan cepat tanggap mengikuti perubahan lingkungan, untuk mewujudkan terselenggaranya aktivitas di sektor kelautan dan perikanan yang andal, dan mempunyai daya saing global.

\section{KAJIAN TEORI DAN METODE Supply Chain Management}

Istilah Supply Chain Management (SCM) dikemukakan pada tahun 1982 oleh Keith Oliver konsultan manajemen di Booz Allen Hamilton (Russell, 2007). Oliver menggunakan istilah tersebut untuk menghancurkan pembatas fungsional yang memisahkan produksi, pemasaran, dan distribusi. Konsep ini dikembangkan oleh J.B. Houlihan pada tahun 1985 ketika ia menjelaskan keterkaitan antara efisiensi dan keuntungan bersama, terkait dengan saling berbagi informasi dan koordinasi keputusan sebuah SC.

Banyak industri memberi perhatian terhadap SCM karena kesadaran akan pentingnya menciptakan hubungan yang terintegrasi dengan pemasok dan pelanggan (Misra et al., 2010). Dalam SCM, pergerakan produk dari titik awal sampai ke pelanggan melibatkan transportasi. Karena itu, transportasi dapat dikatakan sangat signifikan dalam SC, karena hampir semua produk diproduksi dan dikonsumsi di lokasi yang berbeda. Selain itu, transportasi juga merupakan faktor biaya yang signifikan dalam SC (Sadegheih et al., 2010).

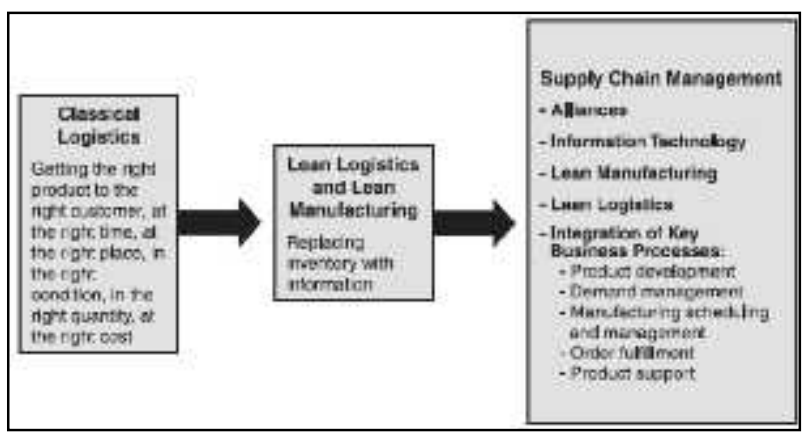

Gambar 1. Transisi konsep dari Logistik Klasik ke Supply Chain Management (Russell, 2007)

SC pada awalnya hanya dipandang sebagai perpanjangan dari konteks tradisional seperti operasi, pembelian dan logistik. Namun, dalam dekade terakhir, penelitian SCM telah berkembang dan diperluas untuk mencakup berbagai perspektif seperti hubungan pemasok, struktur jaringan SC dan kolaborasi (Cook et al., 2011). SCM dibangun dengan dasar sistem informasi. SCM meliputi operasi manufaktur, alat penghubung dengan proses pemasaran dan keuangan, dan melibatkan konsep- konsep antara lain sumber strategis, konektivitas proses bisnis, pembagian risiko, dan keterlibatan pemasok dalam pengembangan produk baru (Russell, 2007). Gambar 1 menunjukkan transisi konsep logistik klasik menjadi SCM.

\section{Supply Chain Industri Perikanan}

Secara konseptual, SC merupakan suatu sistem ekonomi yang mendistribusikan manfaat serta risiko di antara pelaku yang terlibat di dalamnya. Keterkaitan dari berbagai proses harus dapat menciptakan nilai tambah produk kelautan dan perikanan, sehingga setiap pelaku dalam rantai mampu mengkoordinasikan aktivitasnya, baik secara kuantitas, lokasi maupun waktu dengan tepat, untuk memuaskan kebutuhan pelanggan (Wang, 2010). Pengelolaan SC akan bisa berjalan secara optimal apabila ada suatu sinergi antara seluruh komponen yang terlibat dalam setiap aktivitas dari hulu hingga hilir (Ketchen and Hult, 2007).

Produk kelautan dan perikanan memiliki karakteristik berbeda dibandingkan dengan produk lain. Produk ini memiliki sifat umur penggunaan yang pendek serta tingkat kerentanan yang tinggi terhadap cuaca, sehingga diperlukan penanganan khusus dalam proses pengepakan dan distribusinya, guna mempertahankan kualitas produk tersebut. Proses pendistribusian perikanan terkait erat dengan SCM. Distribusi hasil perikanan relatif masih menemui banyak tantangan. Hal ini ditandai antara lain oleh disparitas harga produk yang relatif tinggi, panjangnya rantai pemasaran, marjin keuntungan yang belum proporsional, kualitas serta kontinuitas ketersediaan produk. Pada gilirannya, pihak konsumen akan menanggung masalah distribusi ini dengan membayar harga produk yang tidak wajar.

\section{Agile Supply Chain (ASC)}

Asal-usul agile sebagai konsep bisnis terletak sebagian dalam Flexibility Manufacturing System (FMS). Awalnya dipikirkan bahwa jalur fleksibilitas manufaktur adalah melalui otomatisasi untuk memungkinkan pergantian yang cepat (yaitu waktu set-up yang dikurangi) dan dengan demikian memungkinkan respons yang lebih besar terhadap perubahan dalam bauran produk atau volume (Aitken et al., 2002). Kelincahan merupakan kemampuan untuk merespon dengan cepat perubahan jangka pendek dalam permintaan atau penawaran (Lee, 2004). Kelincahan juga didefinisikan sebagai kemampuan untuk memproduksi berbagai macam produk berkualitas tinggi dengan biaya rendah dengan lead time pendek dalam berbagai ukuran lot, yang dibangun untuk spesifikasi pelanggan individu (Fliedner and Vokurka, 1997). Sedangkan Mason-Jones et al. (2000) menyatakan bahwa kelincahan berarti 
menggunakan pengetahuan pasar dan perusahaan virtual untuk mengeksploitasi peluang menguntungkan di pasar yang bergejolak. Kemudian ide fleksibilitas manufaktur diperpanjang ke dalam konteks bisnis yang lebih luas (Nagel et al., 1991) sampai lahirnya konsep agility sebagai orientasi organisasi.

Naylor et al. (1999) memberikan definisi yang berguna dari dua paradigma sebagai berikut:

"Agility means using market knowledge and a virtual corporation to exploit profitable opportunities in a volatile marketplace."

"Leanness means developing a value stream to eliminate all waste including time, and to enable a level schedule."

Terdapat empat kategori atribut kapabilitas dari agility yaitu responsiveness, competencies, flexibility, dan quickness. Responsiveness merupakan kemampuan untuk mengidentifikasi perubahan dan merespon perubahan tersebut secara cepat. Competencies merupakan kemampuan untuk memberikan produktivitas, efisiensi, dan efektivitas aktivitas bisnis untuk mendapat tujuan perusahaan. Flexibility merupakan kemampuan memproses produk yang berbeda dengan fasilitas yang sama yaitu mencakup fleksibilitas volume produk, model produk, dan isu organisasi. Quickness merupakan kemampuan untuk menyelesaikan tugas-tugas dan kegiatan operasi dalam waktu yang paling pendek, mencakup pengenalan produk baru, kecepatan pengiriman produk dan jasa, dan kecepatan waktu operasi.

\section{Alur Penelitian}

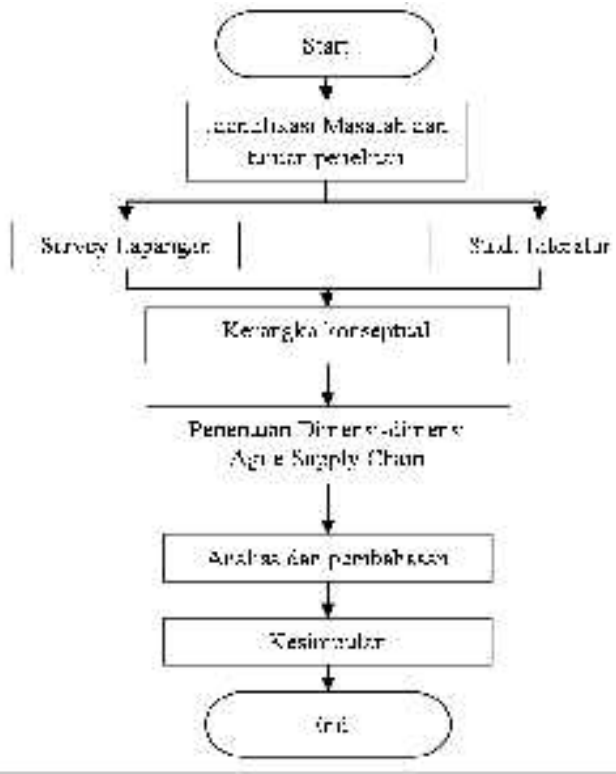

\section{Gambar 2. Diagram Alir Penelitian}

Penelitian ini menggunakan analisis teori dan metode penelitian lapangan. Diagram alir Penelitian ditunjukkan pada Gambar 2. Adapun literatur buku dan jurnal ilmiah yang relevan dengan masalah yang diteliti diperlukan sebagai bahan utama dalam penelitian ini. Berdasarkan survei lapangan dan studi literatur, dikembangkan dan diformulasikan kerangka konsep ASC Industri Perikanan di Kota Ambon. Konsep dasar ini akan diverifikasi lewat penelitian verifikasi, untuk mendapatkan konsep dasar ASC industri perikanan di Kota Ambon.

\section{HASIL DAN PEMBAHASAN}

\section{Perusahaan Perikanan di Kota Ambon}

Provinsi Maluku merupakan Provinsi Kepulauan dengan total luas lautan sebesar 92,4\% dari luas keseluruhannya. Perikanan Maluku disokong oleh tiga fishing ground utama Indonesia yaitu Laut Banda, Laut Arafura, Laut Seram yang masuk dalam Wilayah Pengelolaan Perikanan (WPP) Maluku. Diperkirakan, tiga fishing ground utama ini memiliki potensi sumberdaya perikanan sebesar 1,63 juta ton per tahun dan jumlah tangkapan yang diperbolehkan (JBT) 1,30 juta ton/tahun. Potensi sumberdaya ikan di Maluku ini 26,3 persen dari potensi nasional yang mencapai 6,5 juta ton/tahun ("Potensi Bisnis dan Investasi Perikanan,” 2018)..

Potensi ekonomi sektor kelautan dan perikanan dapat dijabarkan menjadi 5 (lima) kelompok pengembangan meliputi:

1. Pengembangan kekayaan laut non ikan dan energi laut,

2. Pengembangan kapal perikanan, termasuk industri galangan kapal,

3. Pengembangan jasa kelautan berupa industri jasa pelabuhan, dalam hal ini pelabuhan perikanan,

4. Pengembangan pariwisata bahari, dan

5. Pengembangan usaha perikanan, baik perikanan tangkap maupun budidaya.

Saat ini terdapat 13 industri pengolahan ikan (Tabel 1), yang masih beroperasi di kota Ambon. Jumlah ini diperoleh melalui data sekunder yaitu penelitian-penelitian sebelumnya ataupun sumber dari internet, serta peninjauan langsung ke lokasi industri perikanan dimaksud.

Produksi perikanan tangkap dari perairan laut secara garis besar terdiri dari kelompok ikan pelagis, kelompok ikan demersal, dan kelompok non-ikan (krustacea dan moluska). Produksi ikan ekonomis penting pada kelompok ikan pelagis didominasi oleh 5 jenis ikan, yaitu: cakalang, tongkol komo, kembung, tembang dan gulama/tiga waja. Sementara, untuk kelompok ikan demersal, produksi ikan yang bernilai ekonomi pentingnya didominasi oleh jenis ikan: kuwe, lencam, kakap merah, beloso/buntut kerbo dan biji nangka. Selanjutnya, untuk kelompok non-ikan yang bernikai ekonomis penting, produksinya didominasi oleh jenis: rajungan dan udang putih/jerbung (krustacea) serta cumi-cumi (moluska). 
Tabel 1. Daftar Industri Pengolahan Ikan di Kota Ambon

\begin{tabular}{|c|l|l|}
\hline No. & \multicolumn{1}{|c|}{ Nama } & \multicolumn{1}{|c|}{ Lokasi } \\
\hline 1 & $\begin{array}{l}\text { PT. S \& T Mitra Mina } \\
\text { Industries }\end{array}$ & Gudang Arang \\
\hline 2 & PT. Mina Maluku Sejahtera & PPI Erie \\
\hline 3 & CV. As Verzon Jaya & Hative Besar \\
\hline 4 & $\begin{array}{l}\text { PT. Perikanan Nusantara } \\
\text { (Persero) Cabang Ambon }\end{array}$ & Galala \\
\hline 5 & PT. Samudera Sakti Sepakat & Laha \\
\hline 6 & $\begin{array}{l}\text { PT. Arabikatama Khatulistiwa } \\
\text { Fishing Industri (AKFI) }\end{array}$ & Laha \\
\hline 7 & PT. Maluku Prima Makmur & Tawiri \\
\hline 8 & PT. Harta Samudra & PPN Tantui \\
\hline 9 & PT. Sumber Laut Utama & PPN Tantui \\
\hline 10 & PT. Harta Laut Cemerlang & PPN Tantui \\
\hline 11 & Fa. Sanu & PPN Tantui \\
\hline 12 & CV. Tuna Maluku & PPN Tantui \\
\hline 13 & PT. Tri Satria Samudera & PPN Tantui \\
\hline
\end{tabular}

\section{Rantai Pasokan Industri Pengolahan Ikan}

Dalam rantai pasokan industri perikanan, terdapat tiga macam aliran yang harus dikelola. Pertama adalah aliran produk dari hulu (upstream) ke hilir (downstream), kedua adalah aliran uang yang mengalir dari hilir ke hulu, dan yang ketiga adalah aliran informasi yang mengalir dari hulu ke hilir maupun dari hilir ke hulu. Gambar 3 menunjukkan struktur aliran produk rantai pasok industri perikanan yang ada saat ini.

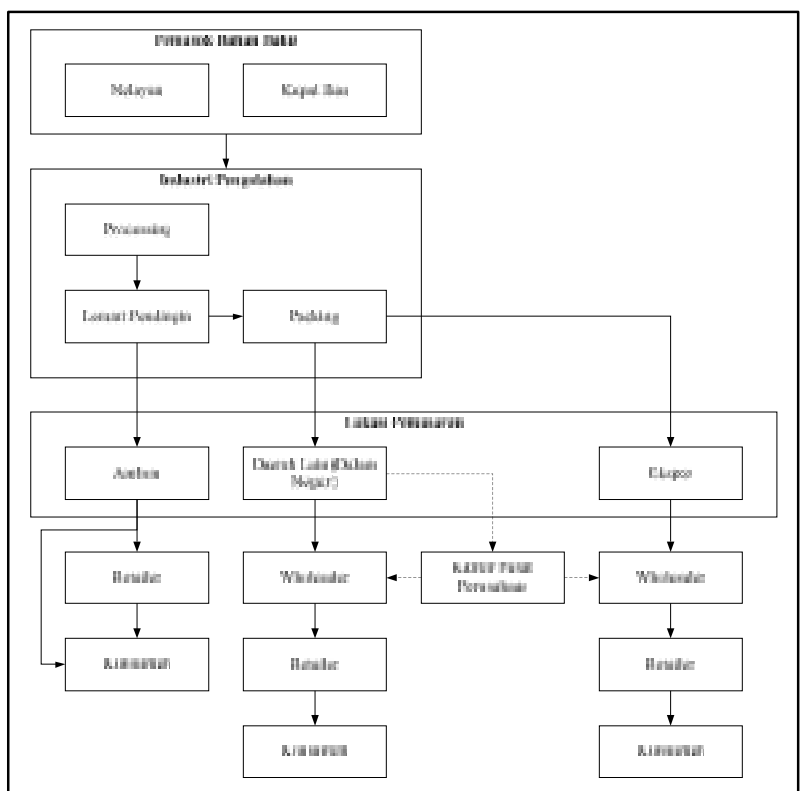

Gambar 3. Struktur Rantai Pasok Industri Perikanan

Adaptasi dari Rumteh (2017)

Pemasok bahan baku utama dalam rantai pasokan industri perikanan adalah nelayan atau kapal ikan milik perusahaan dan pribadi. Mayoritas nelayan merupakan mitra perusahaan. Kapasitas hasil tangkapan nelayan sangat tergantung dari kondisi cuaca yang terjadi. Sebelum diproses, bahan baku disortir, dan dipisahkan antara konsumsi lokal dan untuk ekspor. Setelah diproses, ikan kemudian dimasukkan ke dalam lemari pendingin untuk pembekuan. Untuk ikan yang dipasarkan ke pasar lokal Ambon, bisa langsung dijual ke retailer ataupun langsung ke konsumen. Sementara untuk ekspor, ikan dikemas untuk kemudian diekspor ke luar negeri. Mayoritas produk dari perusahaan perikanan yang ada, umumnya diekspor ke luar negeri. Hanya sedikit yang dijual langsung ke masyarakat.

\section{Model ASC Industri Perikanan}

Agile SC memiliki sejumlah karakteristik yang dikemukakan oleh Harrison et al (1999) (Christopher et al., 2004) yaitu:

- Market sensitive - yaitu selalu terkait dengan tren konsumen akhir.

- Virtual integration-yaitu bergantung pada berbagi informasi di semua mitra rantai pasok.

- Network-based - yaitu mendapatkan fleksibilitas dengan menggunakan kekuatan mitra spesialis.

- Process aligned-yaitu memiliki tingkat interkoneksi proses yang tinggi antara anggota jaringan.

Keempat karakteristik kunci ini dapat dilihat pada Gambar 4, untuk menciptakan ASC bagi industri perikanan.

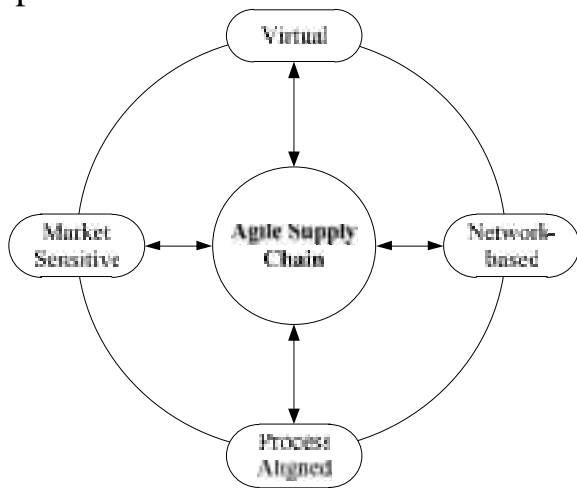

Gambar 4. Konsep Agility SC Industri Perikanan

\section{Market Sensitive}

Dekat dengan pelanggan selalu menjadi tujuan dari setiap bisnis yang berorientasi pasar. Industri perikanan dengan produk yang tidak tahan lama, tentu ingin selalu menjual dengan cepat. Akan tetapi, terdapat pula kondisi dimana pasokan berkurang, karena cuaca atau hal lain.

Kemampuan industri memenuhi preferensi konsumen, terutama menyangkut kualitas produknya, tentu akan menempatkan perusahaan pada posisi yang unggul. Produk industri perikanan merupakan produk yang tidak tahan lama, atau sangat cepat rusak. Kecepatan penanganan produk sejak diterima sampai selesai pemrosesan menjadi hal penting yang harus terus diperhatikan perusahaan. Satu-satunya cara mempertahankan kualitas produk perikanan adalah dengan 
pendinginan. Perusahaan harus mampu mempertahankan suhu lemari pendingin agar ikan membeku dan proses pembusukan tidak terjadi.

\section{Virtual integration}

Agile SC terintegrasi secara virtual, dalam arti bahwa industri perikanan terhubung dan terintegrasi melalui berbagi informasi permintaan real, sehingga semua pemain dalam rantai, dari pemasok ikan, industri pengolahan sampai ke pengecer, semuanya bekerja untuk satu tujuan yang sama. Pengecer dan pemasoknya harus lebih erat terhubung melalui berbagi informasi.

Berbagi informasi mengacu pada sejauh mana informasi kritis dikomunikasikan ke mitra rantai pasok yang lain (Monczka et al., 1998). Saat ini, perusahaan tidak beroperasi sendiri; Mereka sekarang telah terhubung ke banyak mitra lainnya (Mourtzis, 2011). Berbagi informasi berarti mendistribusikan informasi bermanfaat untuk sistem, orang atau unit organisasi. Untuk meningkatkan hasil berbagi informasi, organisasi harus menjawab empat pertanyaan utama: Pertama, kita bertanya apa yang harus dibagikan, lalu siapa yang bisa membaginya, lalu bagaimana cara berbagi, dan akhirnya kapan harus berbagi. Istilah 'Berbagi Informasi' juga dapat disebut sebagai 'Berbagi Pengetahuan' atau 'Integrasi Informasi'. Ada segudang informasi dalam rantai pasok, seperti logistik, bisnis, strategis, taktis dan banyak lagi. Dampak pembagian informasi pada rantai pasokan menjadi lebih signifikan dengan kemajuan teknologi informasi (TI) baru-baru ini. Selanjutnya, beberapa penyelidikan telah dilakukan untuk fokus pada dampak berbagi informasi terhadap kualitas produk. Namun, masih ada ruang untuk studi lebih lanjut untuk mengklarifikasi dengan tepat bagaimana dan informasi apa yang harus dibagi dan efek menguntungkan pada peningkatan kualitas (Tsung, 2000). Hasil penelitian Gichuru et al. (2015) menunjukkan bahwa berbagi informasi berpengaruh positif pada kinerja perusahaan.

\section{Network-based}

Salah satu ciri penting yang membedakan perusahaan yang lincah adalah penggunaan pengaturan yang fleksibel dengan basis pasokan yang luas. Industri tidak terikat pada sejumlah kecil pemasok, tetapi secara luas memilih pemasok dengan jumlah besar, dengan standar kualitas yang tetap terjaga. Kondisi ini memungkinkan pasokan tetap terjaga dalam jumlah dan kualitasnya, sehingga industri tetap bisa berproduksi.

Prinsip di balik jaringan lincah dalam beberapa hal bertentangan dengan gagasan yang berlaku selama ini, bahwa organisasi harus bekerja dengan lebih sedikit pemasok, tetapi dalam jangka waktu yang lebih panjang. Sebaliknya dalam jaringan lincah ada kecenderungan bagi perusahaan untuk bertindak sebagai "orkestrator" dari jaringan, dimana keanggotaan yang akan berubah sesuai dengan persyaratan.

\section{Process aligned}

Rantai pasokan yang responsif memerlukan tingkat penyelarasan proses yang tinggi, baik di internal perusahaan maupun secara eksternal dengan mitra hulu dan hilir. Dengan proses penyelarasan berarti kemampuan untuk membuat koneksi "tanpa batas". Dalam jaringan yang lincah, penyelarasan proses sangat penting dan dimungkinkan dengan adanya aplikasi perangkat lunak baru berbasis Web, yang memungkinkan berbagai entitas untuk dihubungkan meskipun sistem internalnya mungkin sangat berbeda. Saat ini, beberapa organisasi yang secara geografis tersebar dan independen satu sama lain dalam hal kepemilikan, mungkin saja bertindak selayaknya mereka berada dalam satu bisnis.

Rantai pasokan yang tangkas akan memerlukan tingkat integrasi yang lebih tinggi antara proses operasional internal, seperti penjualan, peramalan, perencanaan produksi, pemasok, dan pengiriman. Ketika operasi penjualan merasakan perubahan tren pasar, ini akan memicu reaksi berantai berupa perubahan responsif atau korektif yang melibatkan banyak operasi lain dalam rantai pasokan. Seberapa cepat rantai pasokan dapat bereaksi terhadap perubahan pasar tergantung pada kecepatan perubahan dalam banyak proses internal lainnya. Dengan demikian, proses internal harus diintegrasikan dan berfungsi seolah-olah mereka satu entitas.

\section{KESIMPULAN}

Agile SC memiliki 4 (empat) karakteristik yaitu:

- Market sensitive

- Virtual integration

- Network-based

- Process aligned

1. Kemampuan industri perikanan di Kota Ambon mengelola 4 karakteristik Agile SC akan menyebabkannya mampu bersaing dalam lingkungan persaingan yang semakin ketat saat ini.

2. Penelitian ini masih jauh dari selesai, analisis empiris perlu dilakukan untuk memperkuat kesimpulan terhadap 4 karakteristik Agile SC pada rantai pasok industri perikanan.

3. Perlu dikembangkan sebuah sistem informasi guna mendukung berbagi informasi dan process aligned pada rantai pasok industri perikanan, untuk meningkatkan kelincahan rantai pasok. 


\section{UCAPAN TERIMAKASIH}

Penelitian ini dilaksanakan dengan biaya PNBP Fakultas Teknik Universitas Pattimura tahun 2018. Untuk itu, penulis menyampaikan terima kasih kepada Dekan dan para Wakil Dekan Fakultas Teknik Unpatti serta semua pihak yang telah membantu terlaksananya penelitian ini.

\section{DAFTAR PUSTAKA}

Aitken, J., Christopher, M., Towill, D., 2002. Understanding, Implementing and Exploiting Agility and Leanness. International Journal of Logistics Research and Applications 5, 59-74. https://doi.org/10.1080/13675560110084139

Christopher, M., Lowson, R., Peck, H., 2004. Creating agile supply chains in the fashion industry. International Journal of Retail \& Distribution Management 32, 367-376. https://doi.org/10.1108/09590550410546188

Cook, L.S., Heiser, D.R., Sengupta, K., 2011. The moderating effect of supply chain role on the relationship between supply chain practices and performance: An empirical analysis. Int Jnl Phys Dist \& Log Manage 41, 104-134. https://doi.org/10.1108/09600031111118521

Dirjen Hortikultura, 2008. Membangun Hortikultura Berdasarkan Enam Pilar Pengembangan.

Fliedner, G., Vokurka, R.J., 1997. Agility: Competitive weapon of the 1990s and beyond? Production and Inventory Management Journal $38,19-24$.

Gichuru, M., Iravo, M., Arani, W., 2015. Collaborative Supply Chain Practices on Performance of Food and Beverages Companies: A Case Study of Del Monte Kenya Ltd. International Journal of Academic Research in Business and Social Sciences 5. https://doi.org/10.6007/IJARBSS/v5-i11/1890

Ketchen, D.J., Hult, G.T.M., 2007. Bridging organization theory and supply chain management: The case of best value supply chains. Journal of Operations Management 25, 573-580. https://doi.org/10.1016/j.jom.2006.05.010

Lee, H.L., 2004. The Triple-A Supply Chain [WWW Document]. Harvard Business Review. URL https://hbr.org/2004/10/the-triple-asupply-chain (accessed 8.26.18). Mason-Jones, R., Naylor, B., Towill, D.R., 2000. Engineering the leagile supply chain. Intl Jnl of Agile Mgt Sys 2, 54-61.

https://doi.org/10.1108/14654650010312606

Misra, V., I Khan, M., K Singh, U., N I T Sultanpur, K., 2010. Supply Chain Management Systems: Architecture, Design and Vision. Journal of
Strategic Innovation and Sustainability 6, 102108.

Monczka, R.M., Petersen, K.J., Handfield, R.B., Ragatz, G.L., 1998. Success Factors in Strategic Supplier Alliances: The Buying Company Perspective*. Decision Sciences 29, 553-577. https://doi.org/10.1111/j.1540-

5915.1998.tb01354.x

Mourtzis, D., 2011. Internet based collaboration in the manufacturing supply chain. CIRP Journal of Manufacturing Science and Technology 4, 296-304.

https://doi.org/10.1016/j.cirpj.2011.06.005

Nagel, R., Dove, R., Preiss, K., 1991. 21st Century Manufacturing Enterprise Strategy-an Industry led View.

Naylor, B.J., Naim, M.M., Berry, D., 1999. Leagility: Integrating the lean and agile manufacturing paradigms in the total supply chain. International Journal of Production Economics 62, 107-118. https://doi.org/10.1016/S0925-5273(98)002230

Potensi Bisnis dan Investasi Perikanan [WWW Document], 2018. URL http://www.dpmptspmaluku.com/informasi/bisnis/perikanankelautan (accessed 11.6.18).

Rumteh, K.M., 2017. Pemetaan Awal Supply Chain Management (SCM) Ikan di Ambon (Skripsi). Universitas Pattimura, Ambon.

Russell, S.H., 2007. Supply Chain Management: More Than Integrated Logistics. Air Force Journal of Logistics 31, 55-63.

Sadegheih, A., Li, D., Sribenjachot, S., Drake, P.R., 2010. Applying Mixed Integer Programming for Green Supply Chain Management. The South African Journal of Industrial Engineering 21. http://dx.doi.org/10.7166/21-2-46

Tsung, F., 2000. Impact of information sharing on statistical quality control. IEEE Transactions on Systems, Man, and Cybernetics - Part A: Systems and Humans 30, 211-216. https://doi.org/10.1109/3468.833103

Wang, Y.-L., 2010. International fishery supply chain risk management and insurance, in: 2010 IEEE International Conference on Management of Innovation \& Technology. Presented at the 2010 IEEE International Conference on Management of Innovation \& Technology, pp. 1142-1146. https://doi.org/10.1109/ICMIT.2010.5492903. 